\title{
THE RIGHT TO STRIKE AS A FUNDAMENTAL HUMAN RIGHT: RECOGNITION AND LIMITATIONS IN INTERNATIONAL LAW
}

\author{
EL DERECHO A LA HUELGA COMO UN DERECHO HUMANO \\ FUNDAMENTAL: RECONOCIMIENTO Y LIMITACIONES EN EL \\ DERECHO INTERNACIONAL
}

\section{Jorge Andrés Leyton García*}

\begin{abstract}
The author analyses the recognition of the right to strike as a fundamental human right from an international and comparative perspective. It looks, first, at the way in which different supra-national legal systems recognize the right to strike as a fundamental human right. In a second part, the author analyses some of the limitations to the right to strike that each of these systems allow. Finally, the article concludes by assessing the position of the right to strike as a fundamental human right, taking into account the problems that arise from different forms of recognition and limitation.
\end{abstract}

Key Words: Right to strike, fundamental rights, human rights, International labour standards.

RESUMEN: El autor analiza el reconocimiento del derecho a huelga como un derecho humano fundamental desde una perspectiva internacional y comparada. Mira, en primer lugar, la forma en que diferentes sistemas jurídicos supra-nacionales reconocen el derecho a huelga como derecho humano fundamental. En una segunda parte, el autor analiza algunas de las limitaciones al derecho a huelga que cada uno de estos sistemas permite. Finalmente, el artículo concluye evaluando la posición del derecho a huelga como derecho humano fundamental, teniendo en cuenta los problemas que surgen a partir de las diferentes formas de reconocimiento y limitación.

Palabras clave: Derecho a huelga, derechos fundamentales, derechos humanos, estándares laborales internacionales.

\section{INTRODUCTION}

The question about the nature of labour rights and their relation with human rights remains present in many academic and judicial debates ${ }^{1}$. While hundreds of pages have been spent in discussing whether labour rights can be considered as human rights, the discussion on the practical effects of such categorization has been left in a secondary place.

\footnotetext{
Abogado. Licenciado en Derecho de la Pontificia Universidad Católica de Chile y Master of Laws del University College London, Reino Unido. Profesor del Departamento de Derecho del Trabajo de la Pontificia Universidad Católica de Chile. Dirección Postal: Avenida Libertador Bernardo O’Higgins No 340. Dirección electrónica: jnleyton@uc.cl.

1 For a synthesis of the main arguments of the discussion in the common law field: YoungDaHL (2009) and Compa (2009).
} 
There are of course many reasons to engage in the normative debate: different conceptions about human rights and the foundational values of labour law are in play, and the arguments that support each of them are rooted on important philosophical traditions. This is not, however, the topic of this research. It is not the focus of these pages, first of all, because the outstanding amount of pages spent in the debate have been written over a not-always-recognized consensus: we can all agree that at least some labour rights can be categorized as human rights, since they are so recognized in several international human rights instruments (an argument certainly positivist, but effective as well) ${ }^{2}$. Alongside the theoretical discussion we can find the not less important insight into its practical application.

The practical effects of categorizing labour rights as human rights are in need of further attention and research. A complete research on the various aspects of labour law affected by the human rights discourse extends far beyond the scope of this research, and will probably require years of inter-disciplinary research. There is important ground for analysis, however, if we focus on one of the key issues. The right to strike, in particular, remains as one of the most discussed aspects of labour law. Branded as an essential part of freedom of association by trade unions and scholars, it has been the object of fierce debate at national and international level, as the employer's 2012 standoff at the ILO clearly illustrates. Those who defend the concept of a right to strike emphasize that industrial action is an essential part of freedom of association. Without it, workers and unions lack any strength to defend their positions against the economic and political power of employers.

Assuming that, whether we like it or not, the right to strike can be considered as a fundamental human right creates several questions. An important issue arises when we study, for example, the restrictions imposed to the exercise of the right to strike in different legal systems. We would expect that, being a fundamental human right, courts and other jurisdictional bodies would be wary of imposing or accepting stringent restrictions. Has this been the approach of the courts during the last decades? If not, what reasons have been put forward by the courts to admit broader restrictions? These questions need to be answered if we are to evaluate the practical consequences of the recognition of the right to engage in industrial action-strike as a fundamental human right. We need to look at the way in which courts and other jurisdictional bodies have analysed and framed this right; particularly focusing on how and to what extent will be admissible to restrict it.

To answer the important questions mentioned in the previous paragraphs I will engage in an analysis of the form in which some relevant international bodies have recognized

\footnotetext{
2 An interesting approach to the discussion can be found in Mantouvalou (2009). Mantouvalou identifies three main positions regarding the question of labour rights as human rights. The first, identified as positivistic, argues that certain labour rights are human rights due to their recognition as such in treaties and conventions. A second approach takes an instrumental stance: labour rights will be treated as human rights as long as such recognition can provide an instrument to protect worker's rights at national and international level. If the strategies devised under this assumption fail to provide the expected results, the opinion of those who sustain this position will change radically. Finally, Mantouvalou considers a normative position, developing questions and answers about the human rights and the compatibility of certain labour rights with such definitions. She takes this final position, arguing that there are normative reasons to consider at least certain labour rights as human rights.
} 
and defined the scope and extent of the right to strike. Although the conclusions of the analysis will be developed throughout the following pages and particularly at the end, it is important to mark a point at the outset: the practical protection given to the right to strike by the courts and supervisory bodies that will be scrutinized in these pages is not at all uniform, and the big picture of the right to strike as a fundamental human right is a very complex one, full of contradictions and challenges.

With this in mind, the following pages will be devoted to reflect on the position of three important legal systems at international and European level: The International Labour Organization, The European Convention of Human Rights and Fundamental Freedoms (ECHR) and The European Social Charter. We will look at some important aspects of the right to strike as analysed by each of the courts or supervisory bodies that have interpreted and applied the corresponding treaties. First, we will look at the way in which the right to strike has been recognized as fundamental human right in each of these legal systems. This will involve a small incursion into history, but we shall see that most of the analysis has to be focused in recent legal developments. In the second part of the analysis we will turn to the content and limitations of the right to strike, looking at the activities and objectives protected, as well as some of the most important limitations and interferences that had been addressed in the systems under review. Finally, I intend to develop some conclusions from the analysis performed, pointing out the challenges and contradictions that should be addressed to give clarity and effectiveness to the idea of a fundamental human right to strike. There will be many issues left behind, and the following pages do not intend to be a complete and throughout analysis of a topic that can be addresses from innumerable viewpoints. However, I hope that the arguments contained here can be a useful tool for future critical analysis.

\section{THE RECOGNITION OF THE RIGHT TO STRIKE AS A FUNDAMENTAL HUMAN RIGHT}

The field in which these pages will revolve is indeed complex and full of paradoxes. The right to strike has been recognized in diverse forms in different international and national legal systems. In some cases it has been expressly recognized in the text of conventions and treaties (European Social Charter), while in others the recognition has been achieved through the principled work of supervisory or jurisdictional bodies (like it has been the case in the ILO and the ECHR), not without difficulties and doubts, as we shall see in the following pages. The analysis that follows will show, however, that the form of recognition does not necessary define the scope and extent of the right.

\subsection{The ILO}

Despite being the most important source of labor standards, there is no definition of the right to strike in any of the ILO binding instruments. The right to strike is not mentioned in the ILO Constitution or in the Declaration of Philadelphia, and Convention $\mathrm{N}^{\circ} 87$ on Freedom of Association and Protection of the Right to Organise contains no specific reference to it. There is no textual recognition and no canonical definition in any 
of the Conventions and Recommendations that constitute the ILO's body of norms. Nevertheless, it is fair to say that throughout the history of the ILO there has been a wide consensus among its members regarding the existence of a right to strike which emanates from the dispositions of Convention $\mathrm{N}^{\circ} 87$ as a fundamental aspect of Freedom of Association. As Janice Bellace has pointed out: "Over the past 60 years the ILO constituents have recognized that there is a positive right to strike that is inextricably linked to - and an inevitable corollary of - the right to freedom of association"'.

The recognition of the right to strike as a fundamental right in the context of the ILO standards has been the result of the work performed mainly by two of its supervisory bodies: the Committee on Freedom of Association (a committee of the Governing Body with a tripartite composition) and the Committee of Experts on the Application of Conventions and Recommendations (conformed by independent experts appointed by the Governing Body).

As Gernigon, Odero and Guido have pointed out ${ }^{4}$, both the Committee of Experts and the Committee on Freedom of Association have consistently indicated that there is a fundamental right to strike for workers that emanates from the content of Convention $N^{\circ} 87$, particularly from its articles $3^{5}$ and $10^{6}$. The interpretation given by both Committees is based in the idea, expressed in these articles, that the ILO members are bound to respect and protect the autonomy of employer's and worker's organizations whose purpose is to defend and put forward the interests of their members. The inequality of bargaining power that exists between employers and workers can only be counterbalanced through collective action and industrial action is the only way in which workers can put pressure on the employers to improve labour conditions. As Bellace points out, the Committee on Freedom of Association recognized this reality since its earlier days and considered that the right to strike was an intrinsic aspect of the principle of Freedom of Association that emanated from the ILO's Declaration of Philadelphia and Convention $N^{\circ} 87$. In her words, "it is reasonable to conclude that its members believed that a right to strike was implicit in the Convention's guarantee of freedom of association" ". Hence, this Committee has considered that the right to strike is "an intrinsic corollary to the right to organize protected by Convention No. 87 " 8 and "one of the essential means through which workers and their organizations may promote and defend their economic and social interests". A similar conceptualization can be found in the reports of the Committee of Experts. For example, in their

\footnotetext{
3 Bellace (2014).

4 Gernigon et al. (1998).

5 “Article 3: 1.Workers' and employers' organisations shall have the right to draw up their constitutions and rules, to elect their representatives in full freedom, to organise their administration and activities and to formulate their programmes."

6 "Article 10: In this Convention the term organisation means any organisation of workers or of employers for furthering and defending the interests of workers or of employers."

7 Bellace (2014) p. 48.

8 International Labour Office (2006) p. 109.

9 International Labour Office (2006) p. 109.
} 
2010 Report on the Application of Conventions and Recommendations ${ }^{10}$, the Committee referred to the right to strike in the same terms ${ }^{11}$, remarking the very similar approaches that both bodies have adopted when assessing the position of the right to strike within the ILO standards.

The ILO supervisory system has worked since under the shared understanding that the right to strike is protected by ILO standards, and there has been a wide consensus about its importance in the context of Freedom of Association and trade union rights.

In recent years, however, the ILO forum has been the scenario of a growing polemic regarding the place of the right to strike and the role of the ILO supervisory machinery (particularly the Committee of Experts). The employer's representatives have questioned in strong terms the very existence of a right to strike and have declared that the Committee of Experts has exceeded its mandate by creating what they see as an overreaching and unlimited right to strike with no warrant in the ILO Conventions.

Many of the arguments expressed by the employers are contained in an article written by Alfred Wisskirchen, a former employer spokesperson at the ILO Conference Committee on the Application of Conventions and Recommendations. Most of his article is dedicated to a wider subject: a critique of the state of the ILO's standard setting and supervisory machinery during the last 30 years of the twentieth century. In the final pages of his piece, however, he mounts a strong and direct critique of the way in which the Committee of Experts has performed its task in recent (and not so recent) years. He claims that the Committee has "formulated a comprehensive corpus of minutely detailed strike law which amounts to a far-reaching, unrestricted freedom to strike" ${ }^{12}$. This encompasses with one of his general critiques of the ILO's supervisory machinery: the extent of the mandate of the Committee of Experts. Wisskirchen sees many of the Committee's actions in recent decades as transgressions of the mandate intended when the ILO Conference created it in 1926.

Wisskirchen's emphasis on the right to strike echoes the concerns expressed by employers in the last decades, especially since the end of the Cold War, as Wisskirchen notes in his article ${ }^{13}$. Thus, Wisskirchen's arguments have been reprised by the employer's group in many occasions to support their concerns about the extent and definition of the right to strike. The mandate to define the standards protected by the ILO instruments corresponds to the ILO Conference, they argue, and the only body empowered to provide definitive interpretations of the ILO standards is the International Court of Justice. Since there is no textual recognition of the right to strike, the Committee of Experts -a technical body whose role is to provide inputs for the work of the Conference Committee on the Application of Standards- has overstepped its mandate by, among other things, developing a highly detailed set of principles regarding the definition, extent and limits of the right to strike.

\footnotetext{
10 International Labour Conference (2010).

11 While assessing the compliance of Chile's legislation on the prohibition of a strike in essential services, the Committee indicated that "the right to strike is an intrinsic corollary to the right to organize" (INTERNATIONAL Labour Conference (2010) p. 99).

12 WisSKIRCHEN (2005).

13 WiSSKIRCHEN (2005) p. 288.
} 
To Wisskirchen, the result of this process has been the recognition of an almost unlimited right to strike that has no warrant in Convention $\mathrm{N}^{\circ} 87$.

At this point, it is reasonable to pause and ask some important questions: Is the employer's attack coherent? Can their position be supported in the face of the history and development of ILO standards? Wisskirchen's concern regarding the correct interpretation and application of international norms is to be praised, as well as his support for a reassessment of the impact and importance of ILO standards in a world where globalization and open markets set the tone of industrial relations. There are however, two main flaws in the arguments he and the employer's representatives have used to question the existence of a right to strike in the ILO context.

The first flaw is neglect for some aspects of the history of the ILO's treatment of Freedom of Association and its elements. It is true that the objections raised by the employer's representatives are not new and they have been presented in previous instances, as the document elaborated by the ILO for the 2015 Tripartite meeting rightly notes ${ }^{14}$. It is also true that Wisskirchen addressed briefly the position of the Committee on Freedom of Association as a relevant source for the Committee of Experts when defining the margins of the right to strike. However, he rapidly discards its importance in this particular aspect and neglects the rich case-law developed by this tripartite body through the years regarding the position of the right to strike as a central aspect of Freedom of Association.

But most importantly, the employer's critiques neglects important aspects of the evolution of the ILO's principles on Freedom of Association. Janice Bellace provides an account of this process and shows how the ILO constituents and its supervisory bodies came to embrace the right to strike as an important part of Freedom of Association ${ }^{15}$. Her work shows that, while there is not a clear statement recognizing the right to strike in any Convention, it was gradually accepted as a fundamental right of workers under Convention $\mathrm{N}^{\circ} 87$, a process that involved the main organs of the ILO, and not just the Committee of Experts. The ILO Conference and the Committee on Freedom of Association, among others, were -and still are- key players in the institutional conversation that led the ILO towards the elaboration of a corpus of principles to protect this right. Gernigon, Odero and Guido have also reminded that besides the extensive treatment of the right to strike given by the supervisory bodies, the right to engage in industrial action has also been considered by the ILO Conference -the representative body empowered to define the content of ILO policy and standards, as Wisskirchen also reminds- in at least two occasions. In a resolution adopted in 1957 ("Resolution concerning the Abolition of Anti-Trade Union Legislation in the States Members of the International Labour Organisation" ${ }^{16}$ ), only a few years after the creation of the Committee on Freedom of Association, the ILO Conference asked their members to support and approve laws to protect the rights of trade unions, including ex-

\footnotetext{
14 International Labour Office (2015a) pp. 10-14.

15 Bellace (2014).

16 International Labour Office (1957) p. 783.
} 
pressly the right to strike. A similar recognition was contained in a 1970 declaration ("Resolution concerning Trade Union Rights and Their Relation to Civil Liberties"17).

These declarations are not examples of a systematic treatment of the right to strike -something that would have given more clarity to the subject- but they reinforce the idea that this right has been recognized by the ILO constituents throughout the years, reaching an evolving consensus. Despite the employer's claims expressed in recent years, the ILO supervisory bodies and the ILO Conference have worked for many years under the understanding that Convention $\mathrm{N}^{\circ} 87$ and the principles of Freedom of Association contain a fundamental right to strike. The Committee of Experts has not acted as a maverick in the wilderness; it has fulfilled its role as intended by the ILO constituents.

The second flaw on the employer's arguments touches on the extension of the right that they claim was created by the Committee of Experts. As we noted above, Wisskirchen accuses the Committee of Experts of developing a practically unlimited right to strike which allows for only very limited restrictions. We shall see, following Keith Ewing's ${ }^{18}$ analysis, that the right recognized by the ILO supervisory bodies is far from being an unlimited one. While the ILO regulation is much less restrictive than the ones contained in other legal systems (including the ones to be analysed in these pages), the case law of the Committee of Experts and the Committee on Freedom of Association allows for some important restrictions in its application. The idea of an unlimited right to strike that may threaten the economic stability of a member state is not a plausible scenario under the ILO standards.

As Ewing ${ }^{19}$ and other authors have shown, the employer's attack reached a critical moment in 2012, when the employer's representatives at the Conference Committee on the Application of Standards refused to review any case which involved the right to strike, making it impossible to determine a list of cases for the Conference Committee to review. This effectively paralysed the process of supervision of standards for the first time in the ILO's history. The impasse produced by this was only solved in a special meeting celebrated in February 2015. The employer's and worker's representatives were able to reach a basic agreement regarding the operation of the supervisory system, agreeing to work out on a list of cases for the 2015 supervisory process and setting up a series of steps to review and improve the ILO's supervisory system in general. The government's group reaction (praising the agreement while looking to solve the problems through the official channels) shows that, despite the practical differences, there might be a way to solve the problem in a stable way. However, the statement issued by the parties barely touched the issue of the right to strike. The Final Report of the tripartite meeting showed that the employer's position on the matter of the right to strike has not changed and the differences between both groups remain present. According to the report, the Employer's spokesperson clarified that "the fundamental difference between the Employers and Workers concerning the interpretation of Convention No. 87 in relation to the right to strike remained unresolved, but that this should not prevent the re-establishment of a functioning ILO supervisory system to

\footnotetext{
17 International Labour Office (1970) pp. 733-736.

18 EWING (2013).

19 EWING (2013).
} 
protect workers' rights" ${ }^{20}$. The only mention to the issue of the right to strike in the joint statement seems, however, to be a reason for some level of optimism: "The right to take industrial action by workers and employers in support of their legitimate industrial interests is recognised by the constituents of the International Labour Organisation." ${ }^{21}$

The right to strike is, then, at the heart of ILO standards, and despite having no textual recognition, the consistent work of its supervisory bodies -supported throughout the years by the ILO constituents- has recognized that the right to strike is an essential aspect of Freedom of Association according to Convention N ${ }^{\circ} 87$, the Declaration of Philadelphia and the ILO Constitution. Both history and practice support the existence of a fundamental right to strike. The 2015 Tripartite Meeting's conclusions will have to prove if they can be the base for a sustainable equilibrium towards the future.

\subsection{THE ECHR}

In a situation that resembles the ILO, the European Convention on Human Rights and Fundamental Freedoms (ECHR) does not contain any reference to the right to strike within its text, which has been in force since 1950. Being a classic civil and political rights text, it does not include any of the rights that are usually considered as socio-economic rights. Instead, the countries that form the Council of Europe created a separate instrument containing social, economic and cultural rights (including the right to strike): the European Social Charter, signed in 1961.

The recognition of the right to strike as a fundamental human right in the context of the ECHR has been achieved through the evolution of the case-law of the European Court of Human Rights in Strasbourg (ECtHR). The ECtHR, adopting an interpretative stance which treats the Convention as a "living instrument", has developed in recent years a position that considers that the right to strike is one of the elements contained in Freedom of Association as protected by article $11^{22}$ of the Convention. This position represents an important shift in the interpretation that it gives to article 11. The Court's previous position, expressed clearly in the cases National Union of Belgian Police v Belgium ${ }^{23}$ and Swedish Engine Drivers' Union v. Sweden ${ }^{24}$, sustained that article 11 protects the right of workers to associate and the right of their associations to be heard but it did not granted

\footnotetext{
20 International Labour Office (2015b) p. 8.

21 “The ILO Standards Initiative - Joint Statement of Workers' \& Employers' Groups (23.02.2015)", which can be found in http://www.ilo.org/wcmsp5/groups/public/@ed_norm/@relconf/documents/ meetingdocument/wcms_346764.pdf
}

22 "ARTICLE 11 Freedom of assembly and association: 1. Everyone has the right to freedom of peaceful assembly and to freedom of association with others, including the right to form and to join trade unions for the protection of his interests. 2. No restrictions shall be placed on the exercise of these rights other than such as are prescribed by law and are necessary in a democratic society in the interests of national security or public safety, for the prevention of disorder or crime, for the protection of health or morals or for the protection of the rights and freedoms of others. This Article shall not prevent the imposition of lawful restrictions on the exercise of these rights by members of the armed forces, of the police or of the administration of the State."

23 National Union of Belgian Police V. Belgium (1979-80).

24 SWEDISH ENGINE DRIVERS' UNION V. SWEDEN (1979-80). 
"any particular treatment of trade unions, or their members, by the State (...)"25. It is true that both cases involved the State in its role as an employer, but they were consistently considered as the authority on the matter. Trade union freedom was, therefore, considered as a specific form of freedom of association under article 11, but its protection did not extended to the specific forms in which such freedom could be exercised. There was clearly no room for a specific right to strike under the Convention.

Two main steps synthesize the process that led the ECtHR to recognize the right to strike. It is a process that involves much more than the right to strike, but our focus will be on the importance that it has for its position as a fundamental human right.

The first and most important step was taken in the landmark case of Demir and Baykara v. Turkey ${ }^{26}$. In an extended decision, the Grand Chamber of the Court found a violation of article 11 of the Convention in Turkey's actions towards Tüm Bel Sen, a union of municipal public servants whose collective agreement with a municipal authority was struck down while their legal personality was revoked.

Demir was, then, not a case about the right to strike. It was a case about the right to engage in collective bargaining and the extent to which that right is protected by the guarantee of Freedom of Association contained in article 11 of the Convention. It was also a case about the right of public servants - particularly municipal public servants- to form unions and to engage in collective bargaining. Changing the position sustained until then, the Court decided that trade union freedom under article 11 included the right of workers and their organizations to engage in collective bargaining and to close collective agreements in the pursuit of their members' interest. To reach this conclusion, the Court relied heavily on the principles developed by international bodies, and particularly in the decisions and opinions of the ILO Committee on Freedom of Association and the Committee of Experts. Following their lead, the Court reviewed the evolution of its own case law, from the original position referred above to the recognition of the importance of collective bargaining in Wilson, National Union of Journalists and Others v. United Kingdom ${ }^{27}$, to recognize that the possibility of engaging in collective bargaining and signing collective agreements, being the most important mean by which a trade union could protect and put forward the interests of its members, is one of the essential components of Freedom of Association under article 11. Therefore, states have a duty to protect and promote those elements, something that Turkey had failed to do in the material case.

The second step in this simplified account was given by the Court in the case of Enerji Yapi-Yol Sen v. Turkey ${ }^{28}$. The Turkish government had issued a circular that forbade the participation of public sector employees in a strike scheduled by the Federation of Public Sector Trade Unions, and after some members joined the strike the relevant authorities imposed penalties to them based on the referred circular. The Court accepted the complaint

25 SWEDISH ENGINE DRIVERS' UNION V. SWEDEN (1979-80).

26 DEMIR AND BAYKARA V. TURKEY (2009).

27 WiLSON, NATIONAL UNION OF JOURNALISTS AND Others V. UNITED KINGDOM (2002).

28 ENERI YAPI-YoL SEN V. TURKEY (2009). 
presented by the applicant union and considered that there had been a violation of the guarantee of Freedom of Association in article 11.

To reach this decision, the Court's third section adopted the arguments exposed in the Demir case and the reasoning behind the ILO's recognition of the right to strike. It pointed out that the ILO as well as the European Social Charter recognized the right to strike as an intrinsic corollary of Freedom of Association, and following that argued that while certain prohibitions to engage in strike action can be accepted in certain types of public servants, a general ban was certainly disproportionate and therefore violated the guarantee contained in the Convention. The case has no official version in English language (only in Turkish and French), so the reasons given by the Court can be found in the released legal arguments and in unofficial translations. It seems clear that the Court, by adopting the Demir analysis and the position of the ILO supervisory bodies, is recognizing that the right to strike is one of the most important means for workers to promote their interests. It follows, then, that the right to strike is part of Freedom of Association and therefore protected under article 11 . The consequences of the Court's reasoning appear to be clear, but the decision lacks a systematic analysis of the status of the right to strike as part of Freedom of Association, something that would have been useful in the years to come, as we shall see.

Despite of the lack of a systematic approach to the right to strike, the Court in Enerji had been clear in signalling that the approach taken in Demir led to the recognition of the right to strike in article 11 . The situation was reinforced by the contrast between the positions adopted by the ECtHR and the Court of Justice of the European Union (CJEU), which had delivered two polemic decisions in 2007 (the Laval and Viking cases) in which it had recognized the right to strike as a fundamental right in the EU context (the EU Charter of Fundamental Rights was not at that moment a binding document), but in practice denying any real force to such right when balanced against the employer's freedoms.

The scenario changed, however, with the 2014 decision of the Court in the case of the National Union of Rail, Maritime and Transport Workers v. the United Kingdom ${ }^{29}$. In this case, the Court declined to decide if industrial action (including strikes) had to be considered as an essential element of Freedom of Association under article 11, it declared inadmissible a claim against the UK's legislation requiring strict notice requirements before a strike could be called and considered that a general ban on secondary action complied with the requirements of article 11(2) of the Convention (it was prescribed by law, it pursued a legitimate aim and it is considered necessary in a democratic society). The case appears to be questioning what most commentators assumed to be clear after the line of cases lead by Demir and Enerji. In its decision the Court argued that when the Enerji decision referred to the right to strike as an intrinsic corollary of Freedom of Association, it was merely referring to the position adopted by the ILO supervisory bodies. By not entering in the subject of the essential character of the right to strike as to Freedom of Association and by accepting a total ban on secondary action, the Court has left a mantle of doubt over the real position of the right to strike as a human right protected by the Convention.

29 NATIONAL UNION OF RAIL, Maritime AND TRANSPORT WorKERs V. THE UNITED KINGDOM (2015). 
There have been many conjectures about the real impact of this decision. Two aspects have been prominent. The first points to the fact that the decision corresponds to one of the chambers of the ECtHR (the Demir case was decided by the Grand Chamber, which confirmed a chamber's previous decision). This is a valid point, since the possibility of having a similar case before the Grand Chamber remains open. Its downside, however, is that Enerji and other decisions that gave more strength to the position of the right to strike are also decisions of an individual chamber, and are subject to the same caveat. The second aspect, highlighted by Bogg and Ewing ${ }^{30}$, is the political turmoil that surrounds the relationship between the ECtHR and the UK governments. The growing antipathy of the British political elite towards the decisions of the ECtHR and its impact on the British legal system -which had a climax point with the prisoners' vote case- may have led the Court to take a "softer" approach towards the UK legislation in this occasion. It is not difficult to read the decision with a political perspective (and in the case of an international court, we should have the political component always in mind), but that should not divert our attention from the problems already mentioned.

The big picture of the right to strike in the ECHR context is, then, blurry. There is, however, a recent analysis that brings clarity and coherence to the somehow confusing scenario we have described above. Sadly, it does not correspond to a major decision of the Court, but it might be useful for future decisions. The analysis is contained in a concurring opinion delivered by Judge Pinto de Albuquerque in the recent case of Hrvatski lije ni ki sindikat v. Croatia ${ }^{31}$. Judge Pinto de Albuquerque felt that the unanimous decision of the Court was correct in the material case (it decided that an excessively long process to determine the legality of a strike had the effect of interfering in a disproportionate way with the right to strike of the union under article 11 of the Convention) but it did not touched the core of the issue. He felt necessary to provide a systematic analysis of the reasons that had led the ECtHR to consider that the right to strike is protected under article 11 of the Convention. To do this he made a detailed account of the treatment that the right to strike has received in international law and in the diverse constitutional systems of countries around the world. What is more important, however, is his account of the arguments that led the Court to recognize the right to strike as part of Freedom of Association. In a particularly revealing paragraph, he summarizes the logic behind the evolution of the Court's case-law:

"In the light of Demir and Baykara, cited above, the right of association of workers includes the following essential elements: the right to form and join a trade union, the prohibition of closed-shop agreements, the right to bargain collectively with the employer and the right for a trade union to seek to persuade the employer to hear what it has to say on behalf of its members. In a democratic society, the ultimate practical "means to persuade the employer to hear" the demands of the workers is obviously strike action. If collective action represents the core of the workers' freedom of association, strike action is the core of the core. Indeed, striking predated both unions and collective bargaining. Thus, the taking

30 Bogg And EwIng (2014).

31 HRVATSKI LIJE NI KI SINDIKAT V. CROATIA (2014). 
of strike action should be accorded the status of an essential element of the Article 11 guarantee" 32 .

This account departs from the uncertainties generated by the RMT decision and adopts a firm stance about the status of the right to strike. The right to strike is an essential part of the guarantee contained in article 11 and therefore must be granted the protection that the Convention envisages. Pinto de Albuquerque considers that the Grand Chamber was right to recourse to international norms other than the Convention to assess the Court's position and to read the Convention in the light of the current circumstances. He is right in pointing out that the spirit of the Convention requires this. Being the strike the most crucial element that workers have to put pressure on the employer in the context of labour relations, the logic adopted by the Grand Chamber in Demir requires a step further to recognize the important status that strike action has. The corpus of international norms cited by the Grand Chamber in Demir and repeated in following cases points to that conclusion. To take the path adopted since Demir and to stop at collective bargaining risks rendering Freedom of Association as a toothless and unfulfilled right.

Sadly, Pinto de Albuquerque's account is only an explanation of the interpretation he gives to the ECtHR's case law. It is yet to be seen how influential his position will be in future cases. The ECtHR, and particularly its Grand Chamber, should take in consideration the arguments provided by Judge Pinto de Albuquerque, provide clarity to the position of the right to strike under article 11 and retake the course it adopted with Demir.

\subsection{The European Social Charter and the ECSR}

The original European Social Charter was signed in 1961 by the member states of the Council of Europe, the regional bloc that gave birth to the ECHR a decade before. The Social Charter is an instrument devoted to the protection of those rights that are usually classified as socio-economic. The 1996 revised version of the Charter has not yet been ratified by all of its member states. The body which supervises the conformity of the member states legislation with the provisions of the Social Charter is the European Committee of Social Rights (ECSR), which is composed by 15 independent experts selected by the Council of Europe's Committee of Ministers.

The division between two instruments is not a singularity of the Council of Europe system. However, it has been subject to special criticism throughout its history. The fact that the Social Charter allows member states to ratify a pool of articles they select (under certain limitations) and the existence of a Committee instead of a Court with full interpretative powers to enforce the treaty had been pointed out as evidence of the lower status that the Social Charter appears to have when compared with the ECHR.

Unlike the ILO and the ECHR, the European Social Charter contains a textual protection to the right to strike in its article 6-4:

\section{"Article 6 - The right to bargain collectively}

\footnotetext{
32 Separate Opinion of Judge Pinto de Albuquerque in HRVATSKI LIJE NI KI SINDIKAT V. CROATIA (2014), para 8.
} 
4. the right of workers and employers to collective action in cases of conflicts of interest, including the right to strike, subject to obligations that might arise out of collective agreements previously entered into".

The ECSR has provided a detailed set of principles to define the content and the limits of this right in the context of the Social Charter. Those principles can be found in the ECSR's Conclusions and Statements of Interpretation (emanating from the Committee's reporting procedure) as well as in the decisions on the merits that it delivers in the Collective Complaints procedure.

\subsection{A PRELIMINARY BALANCE}

We have taken some time to analyse how each of the international systems under study recognize the right to strike. Much attention has been given to the ILO and the ECHR because of the complex elements involved in the evolution of their supervisory bodies-courts. With the exception of the European Social Charter, in all of the systems under study there are still relevant debates about the precise status and position of the right to strike, a fact that shows us that the topic is indeed a very controversial one even today. In the following section, we will turn to more practical issues that the right to strike faces when applied or violated in each of these systems, and that process will give more clarity to some aspects. Still, new questions and debates will arise.

\section{THE CONTENT AND LIMITATIONS OF THE RIGHT TO STRIKE}

We have dedicated considerable space to analyse the position of the right to strike among the systems under review. To assess the extent and the limits of the right to strike as a fundamental human right is extremely important to know which forms of activity (and inactivity) can be considered as a strike according to the legal systems we are analysing, as well as some of the requirements that are accepted as preconditions to be fulfilled before engaging in lawful strike action.

\subsection{ACtivities AND ObJeCtives}

As Pinto de Albuquerque rightly pointed out in his opinion cited above, there is not a single definition of what counts as a strike. Even more, it is not an easy task to find a definition of which activities can be considered as a strike. This can be explained by the existence of very diverse systems of industrial relations throughout the world and of different criteria to be applied by national and international legal systems.

Nevertheless, a review of the relevant sources can help us to clarify the issue. Judge Pinto de Albuquerque himself provides us with certain parameters. He indicates that for the purposes of his analysis of the position of the right to strike as a Convention right, a myriad of activities can be considered as a form of strike action. He provides what can be considered as a general definition of what is a strike. He argues that the right to strike "encompasses any work stoppage, however brief and limited, with a view to defending and furthering the workers' interests and rights by exerting pressure on employers, including 
sympathy or secondary strike in the case of workers who take action in support of colleagues employed by another employer" 33 .

Pinto de Albuquerque's definition is a good starting point, since it provides different elements. It contains a certain form of action-inaction ("any work stoppage, however brief and limited") and an intention behind the action ("with a view to defending and furthering the workers' interests and rights by exerting pressure on employers”). It may be a restatement of the obvious, but it is important to keep in mind that any form of work stoppage, in order to be a strike, must have a subjective element, which is to defend and promote the interests of workers by exerting pressure. Pinto de Albuquerque's definition only mentions the employers as the recipients of the pressure, something that may point to a restriction of the ambit and purpose of the right, but in the same paragraph he acknowledges the fact that certain strikes might be directed against general social issues that affect workers.

Let us look at the first element, the activity. The position of the Strasbourg judge is highly influenced, as he recognizes, by the definitions provided by the ILO supervisory bodies. One of the cited sources is the Committee of Experts 1994 General Survey on Freedom of Association, where the Committee provided the central argument taken by Judge Pinto de Albuquerque. The definition, again, refers to any form of work stoppage, without regard to its duration or impact. This marks a trend in the definition of the right to strike provided by the two ILO Committees. Both the Committee of Experts and the Committee on Freedom of Association appear to accept a wide range of possible forms of strike action, with the general limitation of being -and remain- pacific ${ }^{3435}$. Under this frame we can include different forms of industrial action. The most obvious is a complete work stoppage of the workers involved in the conflict, but the Committee of Experts has considered that other forms, despite their different character, may be considered as a strike: this happens with go-slow strikes (which involves a slowdown in work short of a total stoppage) and work-to-rule strikes (when the rules in the workplace are applied to the letter). Mention has also been made to sit-down strikes and wildcat strikes (strikes called by groups of workers without the authorization or command of the union leaders). Pickets (when workers form groups to promote strike action and convince others to engage in it) are also considered as legitimate form of strike action, and the Committee on Freedom of Association has reminded in many occasions that "the action of pickets organized in accordance with the law should not be subject to interference by the public authorities" ${ }^{36}$. The ECSR has also recognized the legitimate position of pickets as an essential form of strike action: "where picketing activity does not violate the right of other workers to choose whether or not to take part in the strike action, the restriction of such activity will amount to a restriction on the right to strike itself, as it is legitimate for striking workers to attempt to involve

\footnotetext{
33 Separate Opinion of Judge Pinto de Albuquerque in HRVATSKI LIJE NI KI SINDIKAT V. CROATIA (2014), para 1 (footnote 1).

34 International Labour Conference (1994) p. 76.

35 International Labour Office (2006) p. 113.

36 Case N²792 (Brazil), Definitive Report- Report No 363, March 2012, para 374.
} 
all their fellow workers in their action" ${ }^{37}$. Again, with all these actions the limit set by the ILO supervisory bodies the pacific character of the activities ${ }^{38}$. The ECSR has added, as we have seen, the importance of the right to work of non-strikers as a relevant consideration. Both ILO supervisory bodies admit that limitations and prohibitions are acceptable if any form of strike action ceases to be peaceful. The ILO constitutes the most important source of definition in this aspect, and most of the references made by other bodies can be traced back to the two supervisory Committees ${ }^{39}$.

The second element, the intention or purpose, leads us to the issue of the objective of a strike. A useful classification has been provided by Gernigon, Odero and Guido ${ }^{40}$. According to these authors, strikes can be divided in occupational, trade union, and political strikes. Occupational strikes, as the name shows, are those that seek to improve the working conditions of the employees. Trade union strikes refer to those actions that intend to defend or promote the position of an organization and/or its leaders. Political strikes, finally, are those strikes aimed at the political decisions taken by the authorities, whether they relate or not to labour and social policies.

For these authors, the first two forms of strikes do not present any problem under the ILO framework: they are clearly protected by the principles of freedom of association developed by the Committee of Experts and the Committee on Freedom of Association. Political strikes, they argue, present a dilemma. Are they protected by the principles of Freedom of Association? The position of both ILO bodies appears to be consistent, as Gernigon, Odero and Guido note. The complex issue, however, is how to define the limit of what forms of political strikes are protected under the ILO framework. The Committee on Freedom of Association has argued that strikes usually cover issues that can be classified as part of the first two categories, "but also the seeking of solutions to economic and social policy questions and problems facing the undertaking which are of direct concern to the workers." ${ }^{41}$. This seems to open the scope of protected motives to the realm of political issues, by incorporating to the acceptable motives issues that are directly related to the policies and decisions of political authorities at different levels. The Committee of Experts has taken a similar approach, by declaring that unions should be able to use strike action "in the search for solutions to problems posed by major social and economic policy trends which have a direct impact on their members and on workers in general, in particular as re-

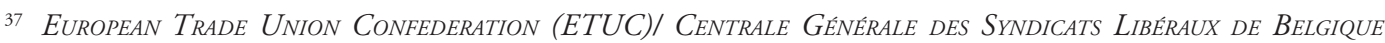

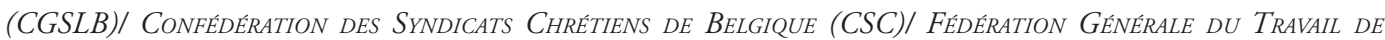
BELGIQUE (FGTB) V. BELGIUM (2011), para 36.

38 "The Committee [on Freedom of Association] also recalls that the right to demonstrate and the right to strike, peacefully exercised, are essential elements of freedom of association" (Case No 2912 (Chile), Definitive Report-Report No 368, June 2013, para 227.

39 Judge Pinto de Albuquerque marked the case of DILEK AND OTHERS V. TURKEY, (App nos. 74611/01, 26876/02 and 27628/02, 17 July 2007) as a recognition of go-slow strikes at ECHR level (at para 57). The case does not have an official English translation, sadly.

40 Gernigon et al. (1998).

41 International Labour Office (2006), p. 110 (also cited in Case N²963 (Chile), Definitive Report-Report No 371, para 236). 
gards employment, social protection and the standard of living.” ${ }^{42}$. Both Committees have defined, however, that strikes with a purely political motivation are not protected by the ILO standards $s^{43}$. There is no clear indication of what is a purely political strike. It seems that the decisive factor to determine if the motivation of a strike is protected under the ILO framework is the connection with the worker's interest. The Committee of Freedom of Association has stated that "While the Committee has always regarded the right to strike as constituting a fundamental right of workers and of their organizations, it has regarded it as such only in so far as it is utilized as a means of defending their economic interests." ${ }^{\prime 4}$. For Gernigon, Odero and Guido, the protection and promotion of the interests of workers plays a key role by "demarcating the boundaries within which the rights and guarantees recognized by the Convention are applicable, and consequently protected in so far as they achieve or seek to achieve the stated objectives" ${ }^{45}$. This requirement, they note, emanates from the text of Convention $\mathrm{N}^{\circ} 87$, specifically its article 10 , which defines worker organizations as those that defend and promote worker's interests. In the end, the limit is hard to apply and the ILO supervisory bodies have recognized that in their decisions, with the result that forms of strike that appear to be completely political may be protected by the ILO principles.

The ECSR has also set a limit on the motivations protected by article 6(4) of the European Social Charter. In a Statement of Interpretation published in the II Conclusions (1971), it noted that political strikes are not protected by the Social Charter. Article 6 of the Social Charter, the Committee argues, is designed to protect collective bargaining, and politically motivated strikes are therefore outside the scope of the protection provided. This position has been sustained throughout the years, and it was again expressed in the XIII-4 Conclusions: "Article 6 para. 4 could not be relied upon to justify strike action taken for political ends" ${ }^{46}$. The emphasis of the ECSR appears to be more restrictive than the ILO's, since it encompasses not only the nature of the motivation (and applying a general criteria regarding all politically motivated strikes) but also an ambit where the right can be exercised (in the context of collective bargaining).

A special mention has to be made about sympathy strikes (secondary action). In these cases the objective of the strike is different: workers not involved in the original conflict where a strike is in place engage in secondary action to support the original strike action. The motive of the strike is solidarity. Are sympathy strikes protected by the right to strike? This is an area where recent developments have marked a stark difference between the position of the ILO supervisory bodies, the ECSR and the European Court of Human Rights.

\footnotetext{
42 International Labour Conference (n 8), 62

43 International Labour Office (2006) pp. 110-111.

44 International Labour Office (2006) p. 109.

45 Gernigon et al. (1998) p. 445.

46 Committee of Independent Experts (1996).
} 
The position of the ILO on this issue has been very clear: sympathy strikes should be permitted subject to the sole requisite that the original strike is lawful ${ }^{47}$. In several occasions, the Committee of Experts and the Committee of Freedom of Association have noted that general bans of secondary action are not compatible with the principles of Freedom of Association contained in Convention $N^{\circ} 87$ and the ILO Constitution ${ }^{48}$. They have denounced that such prohibitions may lead to abuse, and should be avoided.

The ECtHR had an opportunity to address this issue in the recent RMT case. As we commented above, one of the situations denounced by the RMT union was the general ban on secondary action existent in the UK. The ban, as the ECtHR noted in its judgement, had been severely criticized over the years by the Committee of Experts in their reports. The Court also notes that the ECSR had expressed its negative opinion towards the status of British legislation on this issue, which circumscribed protected industrial action to certain specific situations ${ }^{49}$. With these elements in mind (and with the interpretative stance adopted in Demir at sight), the ECtHR decided that the ban on secondary action was indeed an interference with article 11 rights, reaffirming indirectly the position of the right to strike as part of Freedom of Association. It then had to determine if the ban was an acceptable limitation under the terms of article 11(2) of the Convention. The interference was prescribed by law, so the Court had to determine if it pursued a legitimate aim and if the interference was necessary in a democratic society. The Court accepted the arguments provided by the UK Government and considered that the ban pursued the legitimate aim of protecting the rights of rights of others, considering that "by its nature secondary action may well have much broader ramifications than primary action. It has the potential to impinge upon the rights of persons not party to the industrial dispute, to cause broad disruption within the economy and to affect the delivery of services to the public." ${ }^{50}$. Finally, it considered that the UK's general ban on secondary action was necessary in a democratic society.

Different arguments guided the Court to this decision. For them, the interference in the union's rights "was not as invasive as the applicant would have it. What the facts of the case reveal is that the applicant led a strike, albeit on a limited scale and with limited results" ${ }^{51}$. More importantly, the Court considered that the ban did not affected the substance of the rights conferred by article 11, since it considered that secondary action was not a primary form of strike, and not at all a part of the essence of Freedom of Association. We noted above that in this decision the Court considered that it was not necessary to determine if the right to strike as such was an essential element of Freedom of Association. The Court concluded that the Convention provided a wide margin of appreciation to

\footnotetext{
47 International Labour Conference (2010) p. 62.

48 International Labour OfFice (2006) p. 112.

49 In its XX-3 Conclusions, the ECSR referred to the decision reached by the ECtHR in RMT and concluded that "(...) Article $6 \$ 4$ of the Charter is more specific than Article 11 of the Convention. It therefore considers that while the rights at stake may overlap, the obligations on the State under the Charter extend further in their protection of the right to strike, which includes the right to participate in secondary action"

50 National Union of RAIL, Maritime and TRANSPORT Workers V. THE UNITED KingDOM (2015), para 82.

51 National Union of RAIL, Maritime and TRANSPORT Workers V. THE UNITED Kingdom (2015), para 88.
} 
member states on this issue. The UK's general ban was an option within that margin, and it did not affect the essence of the right.

The final result is that a general prohibition on sympathy strikes was established as a valid limitation to the right to strike under the ECHR, putting this objective outside the range of protected motives. The contrast with the positions sustained by the ILO supervisory bodies and the ECSR is clear.

\subsection{Procedural CONTROLS: Ballots, nOtices AND PROCEDURES}

Ewing uses the expression procedural controls to refer to certain duties imposed by states on the unions in order to allow them to engage on lawful strike action ${ }^{52}$. We can extend the concept for the purposes of this analysis and include other forms of control that administrative and judicial bodies can exercise to control the conformity of a particular case of industrial action with the relevant norms. These are serious forms of interference with the right to strike: if a union does not comply with certain formal requirements or intends to engage in a form of strike not allowed under a state's relevant legislation, it may be deprived of the possibility of striking or having immunity for their actions. The extent of the interference is then important to address if we want to assess the practical application of the right to strike.

The ILO supervisory bodies have considered this issue in many occasions. The general principles have been developed around a central idea: to require certain conditions to be met before declaring a strike is compatible with the principles of Freedom of Association, as long as those conditions do not constitute a barrier that makes it too difficult to call and engage in strike action. We need to look at specific cases to assess how this principle has operated in reality. Regarding ballots, the Committee of Experts has accepted they can be required by national legislations as a precondition to initiate strike action, in so far they respect certain limits. For example, a requirement that a ballot should be supervised by the authorities was considered by the Committee as incompatible with the principles of Freedom of Association ${ }^{53}$. Addressing the majorities and quorums required by certain legislations, the Committee has indicated that "the quorum and the majority required should not be such that the exercise of the right to strike becomes very difficult in practice" 54 . The Committee has also analysed situations in which national law obligates unions to exhaust previous instances before calling a strike. To the Committee "it was possible to require the exhaustion of conciliation and mediation procedures before a strike may be called, on condition that the procedures are not so complex or slow that a lawful strike becomes impossible in practice or loses its effectiveness" 55 .

The ECSR has taken a similar position when reviewing the UK's legislation on the subject. In their XX-3 Conclusions (2014), the Committee reiterated that the burden of

\footnotetext{
52 EWING (2013) p. 153.

53 International Labour Conference (2010) p. 62.

54 International Labour Conference (2010) p. 86.

55 International Labour Conference (2015) p. 117.
} 
providing a notice of a ballot and a strike notice to the employer as well was excessive and in breach of the guarantee contained in article 6(4) of the European Social Charter.

The ECtHR had an opportunity to address this issue in recent cases. As we have seen in previous sections, the Court gives important weight and consideration to the opinion of the ILO supervisory bodies when it analyses cases where Freedom of Association is at stake. However, as we have also seen, the position that the ECtHR has departed in several aspects from the principles developed by the ILO. In this issue, the Court has taken a very different approach. The definition of what constitutes a condition or procedure of such complexity as to make it impossible to strike appears to be different than the one we can extract from ILO principles. In the case of Trofimchuk v. Ukraine ${ }^{56}$, the Court considered that a sanction imposed on an employee for her participation in a picket without proper notice was proportionate and complied with the terms of article 11(2) of the Convention. To the Court, the applicant had not done enough to exercise her right to engage in industrial action with due regard to the rights of her employer, since the notice she gave "did not contain an indication of the planned duration of the picket, nor did it suggest that the applicant indented to strike or would otherwise be absent from work because of her participation in the picket"57. The case shows that the ECtHR was prepared to accept that a highly detailed notice could be required before striking without breaching the guarantee contained in article 11 of the Convention.

The issue appears again in a more direct way in the RMT case. As we have noted before, one of the claims presented to the Court involved the UK legislation on strike notice. The company EDF had requested an injunction in British courts to prevent a strike from taking place. They argued that the ballot notice presented by the union did not provided enough details about the workers that would be part of the voting process, since it did not used the precise categories that the company had for each post (it had used the expression "Engineer/Technician"). The injunction was accepted by the Court and the union's appeals were rejected. The union had to postpone the ballot, gather the information and include it in the corresponding notice. Only then it was able to engage in industrial action, and after an improved offer the conflict ended. The union claimed that the norms on ballot notices, which required that the union complied with the considerable amount of details requested by the company, were an excessive restriction to the right to strike contained in article 11 of the Convention. Sadly, the Court declared the application inadmissible in this part and declined to give a substantial analysis of the claim. However, the arguments used by the Court to declare the application inadmissible reveal in a clear way the logic that the Court could apply to assess the conformity of similar requirements with the guarantee of Freedom of Association: "While those requirements have been the subject of criticism by other international bodies (see under part III of the Statement of Facts, above), the Court can only examine complaints in light of their concrete facts. It considers that what the EDF

56 TROFIMCHUK V. UKRAINE (2010).

57 TROFIMCHUK V. UKRAINE (2010), para 46. 
situation discloses in reality is ultimately successful collective action by the applicant on behalf of its members" 58 .

To the Court, the fact that the union was finally able to strike and sign an agreement was an argument powerful enough to consider that the application was ill-founded and had to be rejected. Despite the delays, the costs and the possibly weakened position of the union, the Court considered that the outcome was successful. It is of course out of the question to ask the Court to engage in an assessment of how better would have been the agreement reached if the requirements were lifted or reduced. The argument used by the Court, however, raises the question: If a given legislation requires a union to comply with very stringent requirements or to follow a slow and complex procedure before engaging in industrial action, will the Court consider that if a union is able to strike and reach an agreement then there are not arguments to sustain a claim under the Convention? Will the Court neglect any argument that points to the bargaining position of a union that can only strike after a lengthy process? These are important questions, and the ECtHR will have to address them if it intends to maintain a position with any form of compatibility with the ILO approach.

We have already seen that the Committee of Experts sustains a different position, and both the ILO bodies and the ECSR have been clear in denouncing requirements like the ones contained in the UK's legislation. The Hrvatski lije ni ki sindikat case cannot be considered as a good reference: the process to declare the lawfulness of the strike in this case was considered a disproportionate interference to the right to strike. But it was a process that kept a union without the possibility to strike for a period of three years, an extremely disproportionate interference. It is certainly an extreme case and we should not consider it as a standard. The Court's position might be tested in the future if the amendments $^{59}$ to strike legislation proposed by the current UK government are finally approved. The proposed amendments include more stringent requirements to be fulfilled by a union if it pretends to embark in legal strike action, including higher thresholds for ballots. A challenge to these norms at Strasbourg can provide the ECtHR with an opportunity to reassess its position on the right to strike and give serious consideration to the contradictions existent between its position on the limits of the right to strike and the one contained in the principles developed by the ILO supervisory bodies.

\section{CONCLUSION}

In principle, the recognition of the right to strike as a fundamental human right is a triumph for the aspirations of workers and trade unions around the world. It is the culmination of a long process of struggle that began in the midst of the Industrial Revolution and continued throughout the last two centuries. It began in a moment when worker's or-

\footnotetext{
58 National UNION OF RAIL, MARITIME AND TRANSPORT WorKERS V. THE UNITED KINGDOM (2015), para 45.

59 The Trade Union Bill (HC Bill 58) can be found in http://www.publications.parliament.uk/pa/bills/ cbill/2015-2016/0058/cbill_2015-20160058_en_1.htm
} 
ganizations were proscribed and it advanced until Freedom of Association was recognized as one of the foundations of a stable and long lasting peace.

In these pages we have engaged in a legal analysis of one of the most important results of that process: the recognition of the right to strike as a human right and an essential element of Freedom of Association. We have followed the arguments that led three important international legal systems to recognize this reality and examined some of the characteristics and limitations of the right to strike as a fundamental human right, all in order to understand what this recognition might mean in practical terms for those who engage in strike action. It is of course an incomplete analysis. This work has been focused on some of the hundreds of items that make up a complex and interesting topic.

After this, what can be said about the right to strike and its position as a fundamental human right? As it was pointed out in the introduction, the picture that emerges after analysing the scenario with some detail is a very complex one.

At first sight, the situation appears to be clear: each of the three legal systems we have reviewed recognizes in some way that there is a right to strike within the catalogue of human rights they protect.

However, a closer look shows that there are some problems. The long consensus regarding the position of the right to strike in ILO standards, which allowed the supervisory bodies to protect and promote trade union rights in very different realities, has been replaced with a delicate equilibrium after the 2015 tripartite meeting on the subject. This equilibrium has left behind the paralysis that the 2012 standoff caused in the procedures of the Conference Committee on the Application of Standards, but as the employer's representatives pointed out, it has left the differences on the approach to the right to strike untouched, despite the joint declaration's phrasing.

The situation in the ECHR context is much more complicated. The bold steps taken in Demir and Enerji were received with optimism, as they gave more substance to the guarantee of trade union rights under article 11 of the Convention, and eventually included the right to strike as a part of the elements protected. The situation changed dramatically after the RMT decision. The ECtHR not only questioned the position of the right to strike as an element of Freedom of Association. Its decision narrowed the ambit where the right could be exercised and departed with the position sustained by the ILO. Since Demir the Court had methodically taken into account the principles set by other international systems in the field of labour law, and particularly those developed by the ILO supervisory bodies. After RMT it has taken positions that differ from the ILO's approach, despite continued reference to the work of the Committee of Experts and the Committee on Freedom of Association. The European Social Charter appears to be only safe haven for the right to strike among these systems, with a textual recognition and a Committee that is generating a consistent set of principles. The challenges are greater, however, for a system that allows for many forms of "opt-outs" and is still looked as a softer companion of the ECHR.

On the other hand, the right to strike is, as Ewing has pointed out ${ }^{60}$, a very particular form of human right, subject to many limitations. Despite Wisskirchen's claims, reality

60 EWING (2013). 
shows that it is far from being an unlimited right. Even at the ILO level, where we can find the most detailed and protective treatment of the right to strike, there are several forms of limitations in place. The ILO has accepted as compatible with Freedom of Association regulations on the forms of strike action, the objectives it aims to, the procedures and formalities that must be followed before striking, among many others which can be found on the legal literature. A similar situation can be seen in the case-law of the ECSR and the ECtHR. This last body, as we have seen, has extended the constraints of the right to strike in forms that contradict the principle that it cites as guidance. In an increasingly interconnected labour market, a coordinated approach will soon become a necessity. If the existence of a human right to strike is to have any meaning in future times, legal and political efforts must be focused in protecting the principles developed by the ILO, which have helped to advance the cause of worker's rights in different countries and continents. A similar endeavour will be required to bring the ECtHR back to the path it opened in Demir, and the arguments provided by Judge Pinto de Albuquerque should be taken into account in future decisions about Freedom of Association.

It may be said that the complexities of this issue are not exclusive of the right to strike. After all, most of the rights that have been categorized as social rights have been subject to similar difficulties and inconsistencies. They have all been questioned and subject to several limitations and caveats by courts and legislators. The right to strike has, however, a unique role. The status of the right to strike as a legally enforceable right and the impact that it may have over labour relations is not only a matter of concern for lawyers and scholars, but also for workers and trade unions. The right to engage in collective action has been one of the main values behind the appearance and evolution of labour law during the twentieth century. It is, as judge Pinto de Albuquerque pointed out, "the core of the core" of Freedom of Association, and it is impossible to understand the development of trade union rights without it. Labour law has, as its centre, the concern for the welfare of workers and a concern for the inequality of bargaining between them and the employers, and industrial action has been one of the most effective ways to counterbalance such disparities. The tensions and complexities that have been highlighted in these pages are important factors that must be considered if the existence of a fundamental right to strike is going to have any relevance in the future.

\section{CITED BIBLIOGRAPHY}

Bellace, Janice (2014): “The ILO and the right to strike", International Labour Review, vol. 153, No 1: pp. 29-70.

BogG, Alan and EwIng, KD (2014): “The implications of the RMT case" Industrial Law Journal, vol. 43, Issue 3: pp. 221-252.

Committee of Independent Experts, European Social Charter "Conclusions XIII-4" (1996).

Definitive Report-Report No 363, Committee on freedom of association of the govERNING BODY OF THE ILO, Case N²792 (Brazil) (March 2012). 
Definitive Report-Report No 368, Committee on freedom of association of the GovERNING BODY OF THE ILO, Case No 2912 (Chile) (June 2013).

Definitive Report-Report No 371, Committee on freedom of association of the GovERNING BODY OF THE ILO, Case N²963 (Chile) (March 2014).

Compa, Lance (2009): "Solidarity and Human Rights: A Response to Youngdahl”, New Labor Forum New Labor Forum, Vol. 18, Issue 1: pp 38-45.

European Committee of Social Rights "Statement of Interpretation on Article 6\$4, Conclusions II" (1971).

Decision on the merits, European Committee Of Social Rights "European Trade Union Confederation (ETUC)/Centrale Générale des Syndicats Libéraux de Belgique (CGSLB)/Confédération des Syndicats Chrétiens de Belgique (CSC)/Fédération Générale du Travail de Belgique (FGTB) v. Belgium, Complaint No. 59/2009” (13 september 2011).

European Committee of Social Rights “Conclusions XX-3 (United Kingdom)” (2014).

EwIng, KD and Hendy, John (2010): "The Dramatic Implications of Demir and Baykara”, Industrial Law Journal, Vol. 39, Issue 1: pp. 2-51.

EwING, Keith D. (2013): "Myth and Reality of the Right to Strike as a 'Fundamental Labour Right", The International Journal of Comparative Labour Law and Industrial Relations, Vol. 29, Issue 2: pp. 145-165.

Gernigon, Bernard; Odero, Alberto and Guido, Horacio (1998): "ILO Principles concerning the right to strike", International Labour Review, Vol. 137, No4: pp. 441-482.

International Labour Conference, $81^{\text {st }}$ Session "General Survey of the Reports on the Freedom of Association and the Right to Organize Convention (No. 87), 1948 and the Right to Organize and Collective Bargaining Convention (No. 98), 1949), Report III (Part 4B)" (1994).

International Labour Conference, 99Th Session "Report of the Committee of Experts on the Application of Conventions and Recommendations, Report III (Part 1A) General Report and observations concerning particular countries" (2010).

International Labour Conference, 104Th Session "Report of the Committee of Experts on the Application of Conventions and Recommendations, Report III (Part 1A) General Report and observations concerning particular countries" (2015).

International Labour Office "International Labour Conference Record of Proceedings (40th Session), 1957, Geneva)" (1958).

International Labour Office "International Labour Conference Record of Proceedings (54th Session, 1970, Geneva) (1971).

InTERnATIONAL Labour OfFice "Freedom of Association: Digest of decisions and principles of the Freedom of Association Committee of the Governing Body of the ILO (Fifth (revised edition)" (2006).

International Labour Office "Background document for the Tripartite Meeting on the Freedom of Association and Protection of the Right to Organise Convention, 1948 (No. 87), in relation to the right to strike and the modalities and practices of strike action at national level (revised)" (February, 2015a). 
International Labour Office "Final Report of the Tripartite Meeting on the Freedom of Association and Protection of the Right to Organise Convention, 1948 (No. 87), in relation to the right to strike and the modalities and practices of strike action at national level” (February, 2015b).

International Labour Organization "Tripartite Meeting on the Freedom of Association and Protection of the Right to Organise Convention, 1948 (No. 87), in relation to the right to strike and the modalities and practices of strike action at national level" (February 2015).

Mantouvalou, Virginia (2012): “Are Labour Rights Human Rights?”, European Labour Law Journal, Vol. 3, No2: pp. 151-172.

Parliament of the United Kingdom, "Trade Union Bill (HC Bill 58)" (2015), available at http://www.publications.parliament.uk/pa/bills/cbill/2015-2016/0058/ cbill_2015-20160058_en_1.htm, Date of Consultation: January 17, 2017.

Wisskirchen, Alfred (2005): “The standard-setting and monitoring activity of the ILO: Legal questions and practical experience”, International Labour Review, Vol. 144, Issue 3: pp. 253-289.

Youngdahl, Jay (2009): "Solidarity First: Labor Rights are Not the Same as Human Rights”, New Labor Forum, Vol. 18, Issue 1: pp. 31-37.

\section{CITED CASE LAW}

DEMIR AND BAYKARA V. TURKEY (2009) 48 E.H.R.R. 54.

ENERII YAPI-Yol SEN v. TURKEY App. N68959/01 (ECtHR, 21 April 2009).

HRVATSKI LIJEČNIČKI SINDIKAT V. CROATIA App No 36701/09 (ECtHR, 27 November 2014).

National Union of Belgian Police v. Belgium (1979-80) 1 E.H.R.R. 578.

National UNion of RAIL, MARITIME and TRANSPORT Workers V. THE UNITED KINGDOM (2015) 60 E.H.R.R. 10.

SWEDISH ENGINE DRIVERS' UNION V. SWEDEN (1979-80) 1 E.H.R.R. 617.

TROFIMCHUK V. UKRAINE App N4241/03 (ECtHR, 28 October 2010).

WiLson, National UNion of Journalists and Others V. UNited Kingdom (2002) 35 E.H.R.R. 20. 